\title{
First Total Synthesis of the Phenolic 7,8-Dihydro-8-oxoprotoberberine Alkaloid, Cerasonine
}

\author{
Thanh Nguyen LE and Won-Jea CHO* \\ College of Pharmacy and Research Institute of Drug Development, Chonnam National University; Yong-Bong Dong, Buk- \\ gu, Kwangju 500-757, South Korea. \\ Received February 19, 2008; accepted April 22, 2008; published online April 25, 2008
}

First total synthesis of the phenolic protoberberine, cerasonine, was accomplished through a coupling reaction between $o$-toluamide and benzonitrile. This key step provided the 3 -arylisoquinoline which was then successfully converted to 7,8-dihydro-8-oxoprotoberberine through an intramolecular $S_{N} 2$ reaction.

Key words cerasonine; protoberberine; 3-arylisoquinoline; coupling reaction

Among the natural alkaloids, protoberberines have been one of the main synthetic target molecules due to their diverse pharmacological properties, ${ }^{1)}$ such as antitumor, ${ }^{2)}$ antifungal, ${ }^{3)}$ and antimicrobial ${ }^{4,5)}$ activities. Benzo[c]phenanthridine alkaloids have been biosynthesized from the corresponding protoberberine alkaloids presumably via a 3-arylisoquinoline intermediate. ${ }^{6}$

Cerasonine $1,{ }^{7}$ ) a phenolic protoberberine, was isolated from Polyalthia cerasoides (RoxB.) BedD. (Annonaceae) in 1997 and has not been synthesized yet (Fig. 1).

As a part of our continuous efforts to synthesize all of the different substitution patterns of protoberberines ${ }^{8)}$ we applied our developed synthetic method to the synthesis of

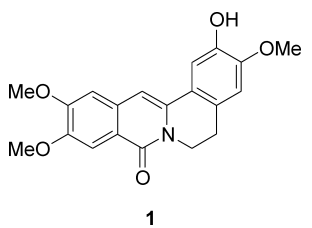

Fig. 1. Structure of the Protoberberine Alkaloid, Cerasonine cerasonine. This strategy was based on preparation of a synthetic intermediate that retains all appropriate substituents on the aromatic rings of cerasonine. For this, a coupling reaction between $N, N$-diethyl-o-toluamide 3 with benzonitrile $\mathbf{4}$ was carried out to yield the 3 -arylisoquinoline 2 , which could be converted to protoberberine via an intramolecular $S_{N} 2$ reaction as depicted in Chart 1. Recently, we efficiently synthesized isoquinolines based on this synthetic route and reported the total synthesis of protoberberine and benzo $[c]$ phenanthridine alkaloids by ring closure of the two carbon chain either on position $2(\mathrm{NH})$ or 4 of the 3-arylisoquinolinone intermediates. $^{9-12)}$ We also succeeded in preparing diversely substituted benzo $[c]$ phenanthridines as well as protoberberines. ${ }^{13)}$ The advantages of our methodology are easy accessibility to the starting materials and a one-pot procedure for construction of all carbon atoms in the alkaloids.

\section{Results and Discussion}

For the coupling reaction, toluamide and benzonitrile were synthesized by the conventional methods described in Charts 2 and 3. Benzyloxybromobenzaldehyde $\mathbf{5}$ was prepared from<smiles>C=CCO[Na]</smiles>

Chart 1. Retrosynthetic Analysis of Cerasonine

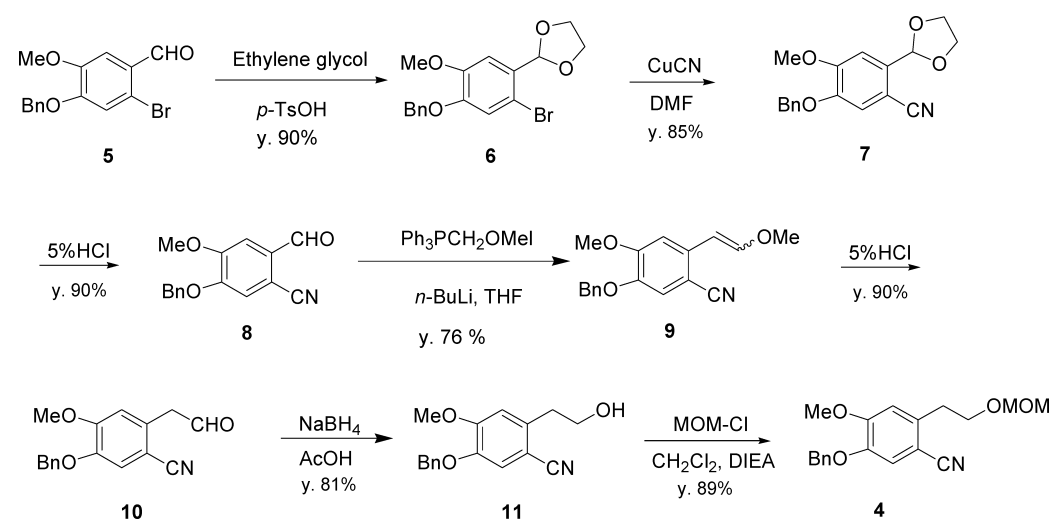

Chart 2. Synthesis of Benzonitrile 4 
vanillin in two steps. ${ }^{14)}$ The aldehyde group of 1 was protected with ethylene glycol and the bromide $\mathbf{6}$ was converted to benzonitrile by treatment with $\mathrm{CuCN}$ in $\mathrm{DMF}$ in $85 \%$ yield. After hydrolysis of the acetal group with $5 \% \mathrm{HCl}$, the resulting aldehyde 8 was reacted with $\mathrm{Ph}_{3} \mathrm{P}^{+} \mathrm{CH}_{2} \mathrm{OMeI}^{-} / n$ BuLi to yield styrene 9 as a cis/trans $(2: 1)$ mixture. Without separation, the isomers were hydrolyzed to produce the homobenzaldehyde, which was then reduced with $\mathrm{NaBH}_{4}$ followed by protection with methoxymethyl chloride to yield the MOM-protected benzonitrile $\mathbf{4}$ in $89 \%$ yield.

The o-toluamide 3 was prepared from 3,4-dimethoxytoluene $\mathbf{1 2}$ in three steps as shown in Chart 3. Vilsmeier reaction of 3,4-dimethoxytoluene $\mathbf{1 2}$ gave the corresponding benzaldehyde $\mathbf{1 3},{ }^{15}$ ) which was then oxidized with $\mathrm{NaClO}_{2}{ }^{16}$ ) to afford the carboxylic acid $\mathbf{1 4}$ in $91 \%$ yield. Treating the benzoic acid 14 with oxalyl chloride and diethylamine gave $N, N$-diethyl $o$-toluamide $\mathbf{3}$ in $90 \%$ yield. ${ }^{17)}$

Once we had the starting materials for the coupling reaction, $N, N$-diethyl-o-toluamide $\mathbf{3}$ was treated with $n$-BuLi and benzonitrile 4 at $-70^{\circ} \mathrm{C}$ in THF to afford 3-arylisoquinoline-1 $(2 H)$-one 15. The MOM protective group was removed with $10 \% \mathrm{HCl}$ to give the alcohol $\mathbf{1 6}$, which was then reacted with $p$-TsCl in DMF in the presence of $\mathrm{K}_{2} \mathrm{CO}_{3}$ to provide the protoberberine 17. Cerasonine 1 was easily obtained in $63 \%$ yield by hydrogenolysis of $\mathbf{1 7}$ in $50 \mathrm{psi}_{2}$ atmosphere with $5 \% \mathrm{Pd} / \mathrm{C}$ catalyst. By comparison of ${ }^{1} \mathrm{H}-\mathrm{NMR}$ data of natural and synthetic compounds as shown in Table 1 and Fig. 2, we synthetically confirmed the structure of cerasonine 1 .

In conclusion, we report here the first total synthesis of phenolic 7,8-dihydro-8-oxoprotoberberine cerasonine in four steps from the toluamide $\mathbf{3}$ and benzonitrile $\mathbf{4}$. Our synthesis illustrates a versatile way to prepare diversely substituted protoberberines, nonphenolic as well as phenolic alkaloids.
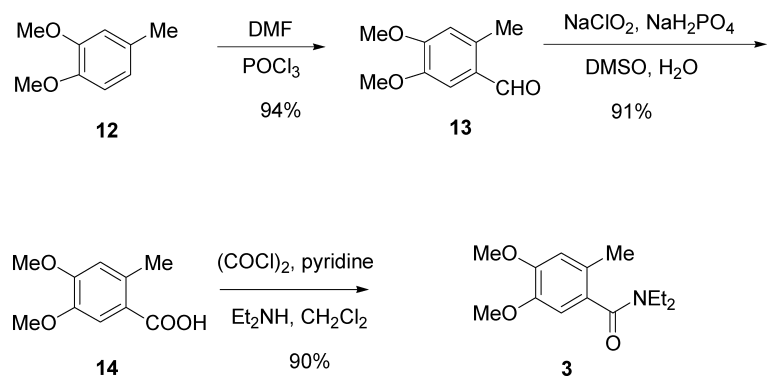

Chart 3. Synthesis of Toluamide 3

\section{Experimental}

Melting points were determined by the capillary method on Electrothermal IA9200 digital melting point apparatus and were uncorrected. Nuclear magnetic resonance (NMR) data for ${ }^{1} \mathrm{H}-\mathrm{NMR}$ were taken on Varian Unity 300 Plus spectrometer and were reported in ppm, downfield from the peak of the internal standard, tetramethylsilane. The data are reported as follows: chemical shift, number of protons, multiplicity ( $\mathrm{s}$ : singlet, $\mathrm{d}$ : doublet, $\mathrm{t}$ : triplet, q: quartet, m: multiplet, b: broadened). IR spectra were recorded on JASCO-FT IR spectrometer using $\mathrm{CHCl}_{3}$ and $\mathrm{KBr}$ pellets. Mass spectra were obtained on JEOL JNS-DX 303 applying the electron-impact (EI) method. Column chromatography was performed on Merck silica gel 60 (70-230 mesh). TLC was performed using plates coated with silica gel 60 F254 that were purchased from Merck.

Chemical reagents were purchased from Aldrich Chemical Co. and used without further purification. Solvents were distilled prior to use: THF and

Table 1. ${ }^{1} \mathrm{H}-\mathrm{NMR}[J(\mathrm{~Hz})]$ Comparison of Natural and Synthetic Cerasonine

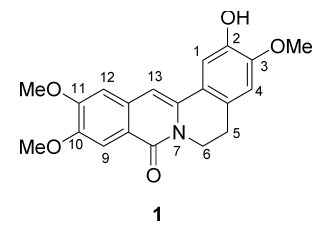

\begin{tabular}{lll}
\hline \hline Position & Synthetic cerasonine & Natural cerasonine $^{7)}$ \\
\hline 1 & 7.35 & 7.23 \\
4 & 6.83 & 6.81 \\
5 & $2.92(J=6.1 \mathrm{~Hz})$ & $2.90(J=5.9 \mathrm{~Hz})$ \\
6 & $4.36(J=6.1 \mathrm{~Hz})$ & $4.34(J=5.9 \mathrm{~Hz})$ \\
9 & 7.80 & 7.80 \\
12 & 6.91 & 6.93 \\
13 & 6.72 & 6.81 \\
$3,10,11$ & $3.94,4.01,4.01$ & $3.99,4.00,4.01$ \\
\hline
\end{tabular}

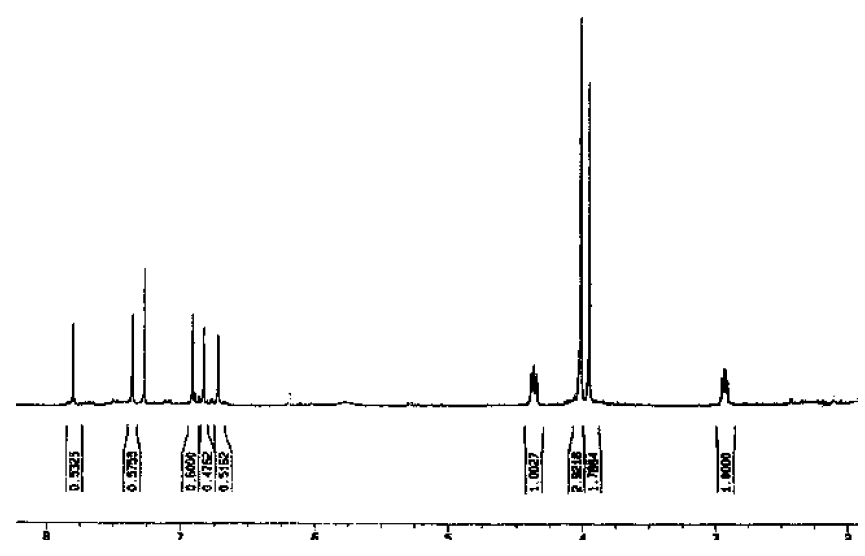

Fig. 2. ${ }^{1} \mathrm{H}-\mathrm{NMR}$ Spectra of Synthetic Cerasonine

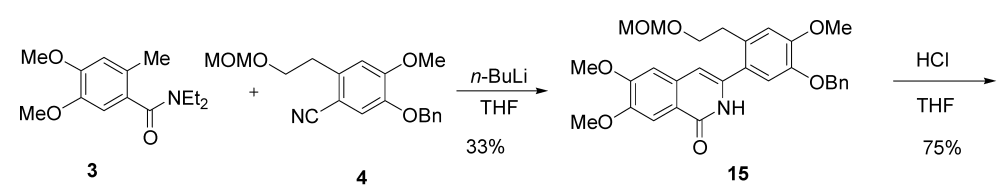

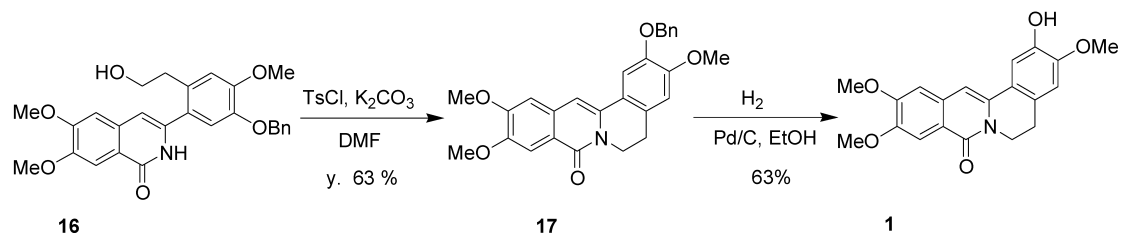


ether were distilled from sodium/benzophenone.

2-(4-Benzyloxy-2-bromo-5-methoxyphenyl)-[1,3]dioxolane

(6) A

mixture of compound $5(22.47 \mathrm{~g}, 70 \mathrm{mmol})$, ethylene glycol $(8.68 \mathrm{~g}, 140$ $\mathrm{mmol})$, and $p$-TsOH $(100 \mathrm{mg}$ ) was refluxed for $3 \mathrm{~h}$ with a Dean-Stark apparatus. The mixture was cooled to $0{ }^{\circ} \mathrm{C}$ and $\mathrm{NaHCO}_{3}(300 \mathrm{mg})$ was added After filtering, the filtrate was concentrated in vacuo to give compound $\mathbf{6}$ as a yellow solid $(23.0 \mathrm{~g}, 90 \%)$ mp: $85-88^{\circ} \mathrm{C} .{ }^{1} \mathrm{H}-\mathrm{NMR}\left(\mathrm{CDCl}_{3}\right) \delta: 7.44$ $7.29(\mathrm{~m}, 5 \mathrm{H}), 7.13(\mathrm{~s}, 3 \mathrm{H}), 7.05(\mathrm{~s}, 1 \mathrm{H}) ; 5.97(\mathrm{~s}, 1 \mathrm{H}), 5.12(\mathrm{~s}, 2 \mathrm{H}), 4.20$ $4.04(\mathrm{~m}, 4 \mathrm{H}), 3.88(\mathrm{~s}, 3 \mathrm{H})$. EI-MS: $m / z 365\left(\mathrm{M}^{+}, 46\right)$. HR-MS-EI (calcd for $\left.\mathrm{C}_{17} \mathrm{H}_{17} \mathrm{BrO}_{4}\right): 365.2376$, found 365.2381

5-Benzyloxy-2-[1,3]dioxolan-2-yl-4-methoxybenzonitrile (7) A mixture of acetal $6(21.9 \mathrm{~g}, 60 \mathrm{mmol})$ and $\mathrm{CuCN}(6.3 \mathrm{~g}, 70 \mathrm{mmol})$ in DMF $(20 \mathrm{ml})$ was refluxed for $2 \mathrm{~h}$. The hot and dark reaction mixture was poured into a warm solution of sodium cyanide $(14.7 \mathrm{~g}, 0.3 \mathrm{~mol})$ in water. The mixture was shaken well and then extracted with benzene. The combined extract was concentrated and column-purified to give benzonitrile 7 as a yellow solid $(15.86 \mathrm{~g}, 85 \%)$ mp: $75-78^{\circ} \mathrm{C}$. IR $\left(\mathrm{cm}^{-1}\right): 2220(\mathrm{CN}) .{ }^{1} \mathrm{H}-\mathrm{NMR}$ $\left(\mathrm{CDCl}_{3}\right) \delta: 7.43-7.32(\mathrm{~m}, 5 \mathrm{H}), 7.11(\mathrm{~s}, 3 \mathrm{H}), 7.11(\mathrm{~s}, 1 \mathrm{H}) ; 5.93(\mathrm{~s}, 1 \mathrm{H}), 5.15$ $(\mathrm{s}, 2 \mathrm{H}), 4.25-4.06(\mathrm{~m}, 4 \mathrm{H}), 3.95(\mathrm{~s}, 3 \mathrm{H})$. EI-MS: $m / z 311\left(\mathrm{M}^{+}, 100\right)$. HRMS-EI (calcd for $\mathrm{C}_{18} \mathrm{H}_{17} \mathrm{NO}_{4}$ ): 311.3468 , found 311.3467 .

5-Benzyloxy-2-formyl-4-methoxybenzonitrile (8) The cyano acetal 7 $(15.55 \mathrm{~g}, 50 \mathrm{mmol})$ in $5 \% \mathrm{HCl}(100 \mathrm{ml})$ was warmed to $50-60^{\circ} \mathrm{C}$ for $15 \mathrm{~min}$. The solid was collected, washed with water and dried in vacuo to give aldehyde 8 as a pale yellow solid $(12.03 \mathrm{~g}, 90 \%)$. mp: $116-118^{\circ} \mathrm{C}$. IR $\left(\mathrm{cm}^{-1}\right): 2230(\mathrm{CN}) .{ }^{1} \mathrm{H}-\mathrm{NMR}\left(\mathrm{CDCl}_{3}\right): \delta 10.24(\mathrm{~s}, 1 \mathrm{H}), 7.50(\mathrm{~s}, 1 \mathrm{H}), 7.43$ $7.36(\mathrm{~m}, 5 \mathrm{H}), 7.20(\mathrm{~s}, 1 \mathrm{H}) ; 5.24(\mathrm{~s}, 2 \mathrm{H}), 3.99(\mathrm{~s}, 3 \mathrm{H})$. EI-MS: $m / z 267\left(\mathrm{M}^{+}\right.$, 57). HR-MS-EI (calcd for $\mathrm{C}_{16} \mathrm{H}_{13} \mathrm{NO}_{3}$ ): 267.2925, found 267.2929.

5-Benzyloxy-4-methoxy-2-(2-methoxyvinyl)benzonitrile (9) To a solution of (methoxymethyl)triphenylphosphonium chloride $(20.52 \mathrm{~g}, 60 \mathrm{mmol})$ in dry THF $(30 \mathrm{ml}), 1.6 \mathrm{M} n$-butyl lithium $(38 \mathrm{ml}, 60 \mathrm{mmol})$ was added at $0{ }^{\circ} \mathrm{C}$ and the solution was stirred at $0{ }^{\circ} \mathrm{C}$ for $1 \mathrm{~h}$. The reaction mixture was then added to aldehyde $8(10.68 \mathrm{~g}, 40 \mathrm{mmol})$ in THF $(30 \mathrm{ml})$. The reaction mixture was stirred at room temperature for $30 \mathrm{~min}$. The reaction was quenched with water and extracted with ethyl acetate. The organic layers were washed with water and brine and dried over sodium sulfate. After removing the solvent, the residue was purified by column chromatography with $n$-hexane-ethyl acetate $(3: 1)$ to afford a mixture of cis/trans isome $\left(2: 1\right.$ ratio) as a yellow solid $(8.97 \mathrm{~g}, 76 \%) .{ }^{1} \mathrm{H}-\mathrm{NMR}\left(300 \mathrm{MHz}, \mathrm{CDCl}_{3}\right) \delta$ (cis): $7.71(\mathrm{~s}, 1 \mathrm{H}), 7.43-7.30(\mathrm{~m}, 5 \mathrm{H}), 7.00(\mathrm{~s}, 1 \mathrm{H}), 6.26(\mathrm{~d}, J=7.2 \mathrm{~Hz}$ $1 \mathrm{H}), 5.55(\mathrm{~d}, J=7.2 \mathrm{~Hz}, 1 \mathrm{H}), 5.12(\mathrm{~s}, 2 \mathrm{H}), 3.93(\mathrm{~s}, 3 \mathrm{H}), 3.83(\mathrm{~s}, 3 \mathrm{H}) . \delta$ (trans): $7.43-7.30(\mathrm{~m}, 5 \mathrm{H}), 7.13(\mathrm{~d}, J=12.9 \mathrm{~Hz}, 1 \mathrm{H}), 6.99(\mathrm{~s}, 1 \mathrm{H}), 6.84(\mathrm{~s}$, $1 \mathrm{H}), 6.02$ (s, 2H), 6.04. (d, $J=12.9 \mathrm{~Hz}, 1 \mathrm{H}), 5.11(\mathrm{~s}, 2 \mathrm{H}), 3.93$ (s, 3H), 3.73 (s, 3H).

5-Benzyloxy-4-methoxy-2-(2-oxo-ethyl)benzonitrile (10) The reaction mixture of cis/trans isomer $9(8.85 \mathrm{~g}, 30 \mathrm{mmol})$ in acetone $(50 \mathrm{ml})$ and $10 \%$ $\mathrm{HCl}(20 \mathrm{ml})$ was refluxed for $3 \mathrm{~h}$. The acetone was removed in vacuo, and the reaction mixture was poured into water and extracted with ethyl acetate. The ethyl acetate extracts were washed with water and brine and dried over anhydrous sodium sulfate. After removing the solvent, the residue was purified by column chromatography on silica gel with $n$-hexane-ethyl acetate $(1: 1)$ to give compound $\mathbf{1 0}$ as a solid $(7.59 \mathrm{~g}, 90 \%)$. mp: $100-103^{\circ} \mathrm{C}$. IR $\left(\mathrm{cm}^{-1}\right): 2220(\mathrm{CN}), 1720(\mathrm{C}=\mathrm{O}), 1300-1000(\mathrm{C}-\mathrm{O}) .{ }^{1} \mathrm{H}-\mathrm{NMR}(300 \mathrm{MHz}$ $\left.\mathrm{CDCl}_{3}\right) \delta: 9.79(\mathrm{~s}, 1 \mathrm{H}), 7.43-7.30(\mathrm{~m}, 5 \mathrm{H}), 7.11(\mathrm{~s}, 1 \mathrm{H}), 6.75(\mathrm{~s}, 1 \mathrm{H}), 5.14$ (s, 2H), $3.92(\mathrm{~s}, 3 \mathrm{H})$. EI-MS: $m / z 281\left(\mathrm{M}^{+}, 100\right)$. HR-MS-EI (calcd for $\left.\mathrm{C}_{17} \mathrm{H}_{15} \mathrm{NO}_{3}\right): 281.2599$, found 281.2897 .

5-Benzyloxy-2-(2-hydroxyethyl)-4-methoxybenzonitrile (11) $\mathrm{NaBH}_{4}$ $(1.52 \mathrm{~g}, 40 \mathrm{mmol})$ was added to a mixture of aldehyde $\mathbf{1 0}(5.62 \mathrm{~g}, 20 \mathrm{mmol})$ in acetic acid $(40 \mathrm{ml})$. After the reaction was over, acetic acid was removed in vacuo and the resulting mixture was poured into water and extracted with ethyl acetate. The organic solvent was evaporated off and the residue was purified by column chromatography with $n$-hexane-ethyl acetate to give alcohol 11 as a yellow solid $(4.59 \mathrm{~g}, 81 \%) \mathrm{mp}$ : $116.5-118.5^{\circ} \mathrm{C}$. IR $\left(\mathrm{cm}^{-1}\right)$ : $3360(\mathrm{OH}), 2220(\mathrm{CN}), 1720(\mathrm{C}=\mathrm{O}), 1300-1000(\mathrm{C}-\mathrm{O}) .{ }^{1} \mathrm{H}-\mathrm{NMR}(300$ $\left.\mathrm{MHz} \mathrm{CDCl}_{3}\right) \delta: 7.43-7.32(\mathrm{~m}, 5 \mathrm{H}), 7.06(\mathrm{~s}, 1 \mathrm{H}), 6.85(\mathrm{~s}, 1 \mathrm{H}), 5.12(\mathrm{~s}$, $2 \mathrm{H}), 3.92(\mathrm{~s}, 3 \mathrm{H}), 3.90(\mathrm{~m}, 2 \mathrm{H}), 3.01(\mathrm{t}, J=6.6 \mathrm{~Hz}, 2 \mathrm{H})$. EI-MS: $m / z 283$ $\left(\mathrm{M}^{+}, 79\right)$. HR-MS-EI (calcd for $\mathrm{C}_{17} \mathrm{H}_{17} \mathrm{NO}_{3}$ ): 283.3358 , found 283.3357 .

5-Benzyloxy-4-methoxy-2-(2-methoxymethoxyethyl)benzonitrile To a mixture of alcohol $11(4.53 \mathrm{~g}, 16 \mathrm{mmol})$ in $\mathrm{CH}_{2} \mathrm{Cl}_{2}$ at $0^{\circ} \mathrm{C}$, diisopropylethylamine $(3.87 \mathrm{~g}, 32 \mathrm{mmol})$ and chloromethylmethyl ether $(2.5 \mathrm{~g}, 32$ mmol) were added. After the reaction was over, $\mathrm{CH}_{2} \mathrm{Cl}_{2}$ was removed in vacuo and the residue was purified by column chromatography with $n$ hexane-ethyl acetate $(3: 1)$ to give benzonitrile 4 as a yellow solid ( $4.64 \mathrm{~g}$, 89\%). mp: $72-74{ }^{\circ} \mathrm{C}$. IR ( $\left.\mathrm{cm}^{-1}\right): 2219(\mathrm{CN}) .{ }^{1} \mathrm{H}-\mathrm{NMR}\left(300 \mathrm{MHz}, \mathrm{CDCl}_{3}\right)$ $\delta: 7.42-7.33(\mathrm{~m}, 5 \mathrm{H}), 7.05(\mathrm{~s}, 1 \mathrm{H}), 6.86(\mathrm{~s}, 1 \mathrm{H}), 5.11(\mathrm{~s}, 2 \mathrm{H}), 4.60(\mathrm{~s}, 2 \mathrm{H})$, $3.92(\mathrm{~s}, 3 \mathrm{H}), 3.78(\mathrm{t}, J=6.6 \mathrm{~Hz}, 2 \mathrm{H}), 3.27-3.92(\mathrm{~s}, 3 \mathrm{H})(\mathrm{s}, 3 \mathrm{H}), 3.05(\mathrm{t}$, $J=6.5 \mathrm{~Hz}, 2 \mathrm{H})$. EI-MS $m / z(\%)$ : $327\left(\mathrm{M}^{+}, 38\right)$. HR-MS-EI (calcd for $\mathrm{C}_{19} \mathrm{H}_{21} \mathrm{NO}_{4}$ ): 327.3902 , found 327.3901 .

6-Methylveratraldehyde (13) Phosphorus oxychloride (24.5 g, 160 $\mathrm{mmol})$ was added to $6.08 \mathrm{~g}(40 \mathrm{mmol})$ of 3,4-dimethoxytoluene under nitrogen with stirring. The mixture was heated to $80^{\circ} \mathrm{C}$, and $11.7 \mathrm{~g}(160 \mathrm{mmol})$ of DMF was added while the reaction temperature was maintained at 90 $95{ }^{\circ} \mathrm{C}$. The mixture was stirred at $95^{\circ} \mathrm{C}$ for $4 \mathrm{~h}$. The dark brown syrup was cooled to $40^{\circ} \mathrm{C}$, poured cautiously onto crushed ice, and extracted with ether. The combined ether extracts were washed with brine, dried, and evaporated in vacuo to give 6-methylveratraldehyde $\mathbf{1 3}$ as a brown oil, which crystallized on standing overnight $(6.73 \mathrm{~g}, 94 \%)$. mp: $73-74{ }^{\circ} \mathrm{C} .{ }^{1} \mathrm{H}-\mathrm{NMR}$ $\left(300 \mathrm{MHz}, \mathrm{CDCl}_{3}\right) \delta: 10.32(\mathrm{~s}, 1 \mathrm{H}), 7.45(\mathrm{~s}, 1 \mathrm{H}), 6.82(\mathrm{~s}, 1 \mathrm{H}), 4.06(\mathrm{~s}, 3 \mathrm{H})$, 4.03 (s, 3H), 2.76 (s, 3H). EI-MS: $m / z 180\left(\mathrm{M}^{+}, 100\right)$.

2-Methyl-4,5-dimethoxybenzoic acid (14) To a stirred mixture of aldehyde $13(6.73 \mathrm{~g}, 37 \mathrm{mmol})$ in DMSO $(50 \mathrm{ml})$ and $\mathrm{NaH}_{2} \mathrm{PO}_{4}(1.8 \mathrm{~g})$ in water $(20 \mathrm{ml})$, a solution of $80 \% \mathrm{NaClO}_{2}(9 \mathrm{~g}, 80 \mathrm{mmol})$ in water $(60 \mathrm{ml})$ was added at room temperature. The reaction mixture stood overnight and then $5 \% \mathrm{NaHCO}_{3}$ solution was added. The aqueous layer was extracted twice with ether and then acidified with $\mathrm{c}-\mathrm{HCl}$. The precipitated carboxylic acid was taken up with $\mathrm{CH}_{2} \mathrm{Cl}_{2}$. The extracts were combined, washed with brine, dried, and evaporated to give the benzoic acid 14 (6.94 g, 95\%). mp: 139 $141{ }^{\circ} \mathrm{C} .{ }^{1} \mathrm{H}-\mathrm{NMR}\left(300 \mathrm{MHz}, \mathrm{CDCl}_{3}\right) \delta: 7.64(\mathrm{~s}, 1 \mathrm{H}), 6.73(\mathrm{~s}, 1 \mathrm{H}), 3.95(\mathrm{~s}$, 1H), 3.95 (s, 6H), 2.63 (s, 3H). EI-MS: $m / z 196\left(\mathrm{M}^{+}, 65\right)$.

2-Methyl-4,5-dimethoxy- $\boldsymbol{N}, \boldsymbol{N}$-diethylbenzamide (3) To a suspension of 2-methyl-4,5-dimethoxybenzoic acid $14(5 \mathrm{~g})$ in $\mathrm{CH}_{2} \mathrm{Cl}_{2}(50 \mathrm{ml})$ containing pyridine $(3.2 \mathrm{~g})$, oxalyl chloride $(17.8 \mathrm{ml})$ was added slowly with stirring. After an additional $2 \mathrm{~h}$ of stirring, the excess oxalyl chloride was removed in vacuo and the last trace of oxalyl chloride was removed by co-distillation with benzene. The obtained acid chloride was dissolved in $\mathrm{CH}_{2} \mathrm{Cl}_{2}(60 \mathrm{ml})$ and carefully treated with diethyl amine $(18.65 \mathrm{~g})$ at $0{ }^{\circ} \mathrm{C}$. The reaction mixture was diluted with water, the organic layer was separated and the aqueous layer was extracted with $\mathrm{CH}_{2} \mathrm{Cl}_{2}$. The organic portions were washed with water and brine, dried, and then evaporated. The residue was purified by column chromatography to give 2-methyl-4,5-dimethoxy- $N, N$-diethylbenzamide 3 as an oil $(5.7 \mathrm{~g}, 90 \%)$. IR $\left(\mathrm{cm}^{-1}\right): 1625(\mathrm{CO}) .{ }^{1} \mathrm{H}-\mathrm{NMR}(300 \mathrm{MHz}$, $\left.\mathrm{CDCl}_{3}\right) \delta: 6.68(\mathrm{~s}, 2 \mathrm{H}), 3.97(\mathrm{~s}, 3 \mathrm{H}), 3.94(\mathrm{~s}, 3 \mathrm{H}), 3.75-2.90(\mathrm{~m}, 4 \mathrm{H}), 2.23$ $(\mathrm{s}, 3 \mathrm{H}), 1.50-0.85(\mathrm{~m}, 6 \mathrm{H})$. EI-MS: $m / z 251\left(\mathrm{M}^{+}, 100\right)$

3-[5-Benzyloxy-4-methoxy-2-(2-methoxymethoxyethyl)phenyl]-6,7dimethoxy-2H-isoquinolin-1-one (15) A solution of $N, N$-diethyltoluamide $3(1.04 \mathrm{~g}, 4 \mathrm{mmol})$ and benzonitrile $4(1.01 \mathrm{~g}, 3 \mathrm{mmol})$ in dry THF $(40 \mathrm{ml})$ were added dropwise to a solution of $n-\mathrm{BuLi}(5 \mathrm{ml}$ of $1.6 \mathrm{M}$ in hexane, $8 \mathrm{mmol})$ in $\mathrm{THF}(30 \mathrm{ml})$ at $-70^{\circ} \mathrm{C}$ and the reaction mixture was stirred at the same temperature for $6 \mathrm{~h}$. The reaction was quenched with water and extracted with ethyl acetate and dried over sodium sulfate. After removing the solvent, the residue was purified by column chromatography with $n$-hexane-ethyl acetate $(1: 1)$ to afford compound $\mathbf{1 5}$ as an orange oil (507 mg, 33\%). IR ( $\left.\mathrm{cm}^{-1}\right): 3400(\mathrm{NH}), 1645(\mathrm{C}=\mathrm{O}) .{ }^{1} \mathrm{H}-\mathrm{NMR}(300 \mathrm{MHz}$, $\left.\mathrm{CDCl}_{3}\right) \delta: 10.4(\mathrm{~b}, 1 \mathrm{H}), 7.78(\mathrm{~s}, 1 \mathrm{H}), 7.42-7.33(\mathrm{~m}, 5 \mathrm{H}), 6.97(\mathrm{~s}, 1 \mathrm{H}), 6.89$ $(\mathrm{s}, 1 \mathrm{H}), 6.81(\mathrm{~s}, 1 \mathrm{H}), 6.33(\mathrm{~s}, 1 \mathrm{H}), 5.19(\mathrm{~s}, 2 \mathrm{H}), 4.72(\mathrm{~s}, 2 \mathrm{H}), 4.00(\mathrm{~s}, 3 \mathrm{H})$, $3.99(\mathrm{~s}, 3 \mathrm{H}), 3.92(\mathrm{~s}, 3 \mathrm{H}), 3.88(\mathrm{~m}, 2 \mathrm{H}), 3.31(\mathrm{~s}, 3 \mathrm{H}), 2.88(\mathrm{~m}, 2 \mathrm{H})$. EI-MS $m / z(\%): 505\left(\mathrm{M}^{+}, 100\right), 414(61), 91$ (53). EI-MS m/z (\%): $505\left(\mathrm{M}^{+}, 35\right)$. HR-MS-EI (calcd for $\mathrm{C}_{29} \mathrm{H}_{31} \mathrm{NO}_{7}$ ): 505.5831 , found 505.5837 .

3-[5-Benzyloxy-2-(2-hydroxy-ethyl)-4-methoxy-phenyl]-6,7-dimethoxy-2H-isoquinolin-1-one (16) To the mixture of compound $\mathbf{1 5}$ $(300 \mathrm{mg}, 0.6 \mathrm{mmol})$ in $\mathrm{THF}(15 \mathrm{ml}), 10 \% \mathrm{HCl}(5 \mathrm{ml})$ was added and the reaction was refluxed for $2 \mathrm{~h}$. The reaction mixture was poured into water and extracted with ethyl acetate. The ethyl acetate extracts were washed with water and brine and dried over anhydrous sodium sulfate. After removing the solvent, the residue was purified by column chromatography on silica gel with $\mathrm{CH}_{2} \mathrm{Cl}_{2}: \mathrm{MeOH}(20: 1)$ to give the alcohol 16 as a yellow solid (205 mg, 75\%). mp: $177-179^{\circ} \mathrm{C}$. IR $\left(\mathrm{cm}^{-1}\right): 3400(\mathrm{NH}, \mathrm{OH}), 1642(\mathrm{C}=\mathrm{O}) .{ }^{1} \mathrm{H}-$ NMR $\left(300 \mathrm{MHz}, \mathrm{CDCl}_{3}\right) \delta: 7.71(\mathrm{~s}, 1 \mathrm{H}), 7.42-7.33(\mathrm{~m}, 5 \mathrm{H}), 6.92(\mathrm{~s}, 1 \mathrm{H})$ $6.88(\mathrm{~s}, 1 \mathrm{H}), 6.82(\mathrm{~s}, 1 \mathrm{H}), 6.36(\mathrm{~s}, 1 \mathrm{H}), 5.11(\mathrm{~s}, 2 \mathrm{H}), 4.13(\mathrm{t}, J=5.4 \mathrm{~Hz}, 2 \mathrm{H})$, $4.06(\mathrm{~s}, 3 \mathrm{H}), 3.99(\mathrm{~s}, 3 \mathrm{H}), 2.81(\mathrm{t}, J=5.4 \mathrm{~Hz}, 2 \mathrm{H})$. EI-MS $m / z(\%): 461\left(\mathrm{M}^{+}\right.$, 38). HR-MS-EI (calcd for $\mathrm{C}_{27} \mathrm{H}_{27} \mathrm{NO}_{6}$ ): 461.5288, found 461.5291. Anal. Calcd for $\mathrm{C}_{27} \mathrm{H}_{27} \mathrm{NO}_{6}$ : C, 70.27; H, 5.90; N, 3.04. Found: C, 70.56; H, 5.79; N, 3.15 .

2-Benzyloxy-3,10,11-trimethoxy-5,6-dihydro-isoquino[3,2-a]isoquinolin-8-one (17) The mixture of compound 16 (170 $\mathrm{mg}, 0.36 \mathrm{mmol})$, tosyl chloride (133 mg, $0.7 \mathrm{mmol})$ and $\mathrm{K}_{2} \mathrm{CO}_{3}(290 \mathrm{mg}, 2.1 \mathrm{mmol})$ in DMF (10 $\mathrm{ml}$ ) was stirred at $100^{\circ} \mathrm{C}$ for $4 \mathrm{~h}$. Water was added and the reaction mixture was extracted with ethyl acetate. The ethyl acetate extracts were washed with water and brine and dried over anhydrous sodium sulfate. After remov- 
ing the solvent, the residue was purified by column chromatography on silica gel with $n$-hexane-ethyl acetate $(1: 2)$ to give 8 -oxyprotoberberine $\mathbf{1 7}$ as a yellow solid $(100 \mathrm{mg}, 63 \%)$. mp: $173-175^{\circ} \mathrm{C}$. IR $\left(\mathrm{cm}^{-1}\right): 1636 .{ }^{1} \mathrm{H}-\mathrm{NMR}$ $\left(300 \mathrm{MHz}, \mathrm{CDCl}_{3}\right) \delta: 7.79(\mathrm{~s}, 1 \mathrm{H}), 7.52-7.41(\mathrm{~m}, 5 \mathrm{H}), 7.30(\mathrm{~s}, 1 \mathrm{H}), 6.89$ $(\mathrm{s}, 1 \mathrm{H}), 6.76(\mathrm{~s}, 1 \mathrm{H}), 6.70(\mathrm{~s}, 1 \mathrm{H}), 5.22(\mathrm{~s}, 2 \mathrm{H}), 4.36(\mathrm{t}, J=6.0 \mathrm{~Hz}, 2 \mathrm{H}), 4.01$ $(\mathrm{s}, 3 \mathrm{H}), 4.01(\mathrm{~s}, 3 \mathrm{H}), 3.94(\mathrm{~s}, 3 \mathrm{H}), 2.88(\mathrm{t}, J=6.0 \mathrm{~Hz}, 2 \mathrm{H})$. EI-MS $\mathrm{m} / z(\%)$ : 443 (M, 100). HR-MS-EI (calcd for $\mathrm{C}_{27} \mathrm{H}_{25} \mathrm{NO}_{5}$ ): 443.5135, found 443.5134 Anal. Calcd for $\mathrm{C}_{27} \mathrm{H}_{25} \mathrm{NO}_{5}$ : C, 73.12; H, 5.68; N, 3.16. Found: C, 73.26; H, $5.76 ; \mathrm{N}, 3.17$

2-Hydroxy-3,10,11-trimethoxy-5,6-dihydro-isoquino[3,2-a] isoquinolin-8-one (1) Cerasonine The mixture of compound $17(80 \mathrm{mg}, 0.18$ $\mathrm{mmol})$ in $\mathrm{EtOH}(10 \mathrm{ml})$ in the presence of $5 \% \mathrm{Pd} / \mathrm{C}(20 \mathrm{mg})$ was treated with $50 \mathrm{psi}_{2}$ for $4 \mathrm{~h}$ using Parr apparatus. After the reacted catalyst was filtered off, the filtrate was washed with $\mathrm{CH}_{2} \mathrm{Cl}_{2}$. The combined organic layer was evaporated off to give a residue that was purified by column chromatography with $n$-hexane-ethyl acetate $(1: 2)$ to yield cerasodine as a white solid (40 mg, 63\%). mp: $>200^{\circ} \mathrm{C}$ (lit. ${ }^{7}$ oil). IR $\left(\mathrm{cm}^{-1}\right): 1649$ (CO). UV (EtOH) $\lambda_{\max }(\log \varepsilon): 230$ (3.56), 259 (3.46), 334 (3.30). ${ }^{1} \mathrm{H}-\mathrm{NMR}\left(300 \mathrm{MHz}, \mathrm{CDCl}_{3}\right)$ $\delta: 7.80(\mathrm{~s}, 1 \mathrm{H}), 7.35(\mathrm{~s}, 1 \mathrm{H}), 6.91(\mathrm{~s}, 1 \mathrm{H}), 6.83(\mathrm{~s}, 1 \mathrm{H}), 6.72(\mathrm{~s}, 1 \mathrm{H}), 5.22(\mathrm{~s}$, $2 \mathrm{H}), 4.36(\mathrm{t}, J=6.1 \mathrm{~Hz}, 2 \mathrm{H}), 4.01(\mathrm{~s}, 3 \mathrm{H}), 4.01(\mathrm{~s}, 3 \mathrm{H}), 3.94(\mathrm{~s}, 3 \mathrm{H}), 2.92(\mathrm{t}$, $J=6.1 \mathrm{~Hz}, 2 \mathrm{H}$ ). EI-MS $m / z(\%): 353$ (M, 100). HR-MS-EI (calcd for $\mathrm{C}_{20} \mathrm{H}_{19} \mathrm{NO}_{5}$ ): 353.3851 , found 353.3852 .

Acknowledgements This work was supported by Korea Research Foundation (KRF) grant (C00325: RO5-2004-000-12578-0).

\section{References}

1) Simanek V., "The Alkaloids," Vol. 26, ed. by Brossi A., Academic Press, Orlando, 1985, pp. 185-240.

2) Min Y. D., Yang M. C., Lee K. H., Kim K. R., Choi S. U., Lee K. R.,
Arch. Pharm. Res., 29, 757-761 (2006).

3) Vollekova A., Kost'alova D., Kettmann V., Toth J., Phytother. Res., 17, 834-837 (2003).

4) Hwang J. M., Kuo H. C., Tseng T. H., Liu J. Y., Chu C. Y., Arch. Toxicol., 80, 62-67 (2006)

5) Faizi S., Khan R. A., Azher S., Khan S. A., Tauseef S., Ahmad A., Planta Med., 69, 350-355 (2003).

6) Takao N., Kamigauchi M., Okada M., Helv. Chim. Acta, 66, 473-484 (1983).

7) Gonzalez M. C., Zafra-Polo M. C., Amparo-Blazquez M., Serrano A., Cortes D., J. Nat. Prod., 60, 108-110 (1997).

8) Le T. N., Gang S. G., Cho W. J., Tetrahedron Lett., 45, 2763-2766 (2004).

9) Le T. N., Cho W. J., Bull. Korean Chem. Soc., 27, 2093-2096 (2006).

10) Cho W. J., Le Q. M., Van H. T. M., Lee K. Y., Kang B. Y., Lee E. S., Lee S. K., Kwon Y., Bioorg. Med. Chem. Lett., 17, 3531-3534 (2007).

11) Van H. T. M., Le Q. M., Lee K. Y., Lee E. S., Kwon Y., Kim T. S., Le T. N., Lee S. H., Cho W. J., Bioorg. Med. Chem. Lett., 17, 3531-3534 (2007).

12) Le T. N., Cho W. J., Chem. Pharm. Bull., 54, 476-480 (2006).

13) Le T. N., Gang S. G., Cho W. J., J. Org. Chem., 69, 2768-2772 (2004).

14) Fukuyama Y., Yaso H., Mori T., Takahashi H., Minami H., Kodama M., Heterocycles, 54, 259-274 (2001).

15) Charlton J. L., Alauddin M. M., J. Org. Chem., 51, 3490-3493 (1986).

16) Dalcanale E., Montanari F., J. Org. Chem., 51, 567-569 (1986).

17) Clark R. D., Jahangir, J. Org. Chem., 53, 2378-2381 (1988). 